\title{
The Of Re-Habilitation Existing Building \\ (An Empirical Study On Foda Tower)
}

\section{Prof. Mohamed Reda Abd ALLAH}

Associate professor, Department of Architecture Faculty of Engineering, Cairo University

\begin{abstract}
Egypt is characterized by a range of buildings and real estate wealth in its various Governorates, these buildings vary between recently used buildings and vacant heritage buildings most of which are unexploited. Nevertheless, what is being discussed is the issue of the existing buildings built in the periods from the early seventies of the last century until the beginning of this century these buildings are unexploited and some of them are incomplete. The reasons for unused of these real state standards are multiple due to economic determinates and other building regulation and codes of civil defense and parking lots or some reasons due to market mechanisms, supply, and demand of the functional spaces in which the building was designed and implemented for. All of these reasons were a direct cause of the lack of exploitation of the building or to perform the function that was designed and carried out for it.
\end{abstract}

The paper addresses the potential of rehabilitation and reusing of the modern building using new innovative ideas to rehabilitate the building for the facilitation of marketing using smart building technology to solve functional rehabilitation problems, such as communication devices and smart air condition - Control rooms to equip and rehabilitate the building to act towards the new functions and maximize the comfort of users. Which is considered a rebirth of the building to implement it to the real state wealth system and maximize its economic benefits. This is what was put forward through the applied study for one of the most famous and unused buildings "Foda Tower" in Giza, Egypt (Al Jazeera Region) for more than forty-five years through this study. Abstract of the research into a group of calibrations for rehabilitation and employment in the framework of operational solutions.

\section{KEYWORDS}

Rehabilitation, unused of Existing Building, Function Analysis, Technology, Foda Tower.

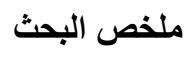

تتميز مصر بمجموعة من المباني و الثروة العقارية في مختلف محافظتها وتتنوع تللك الثروة بين مباني حديثة مستغلة ومباني تر اثية

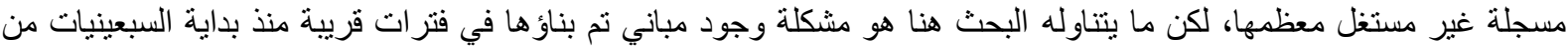

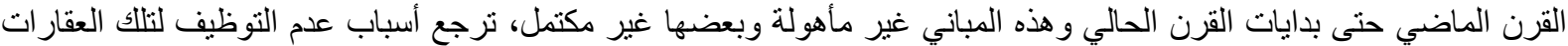

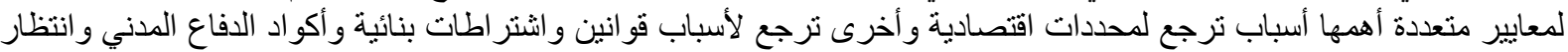

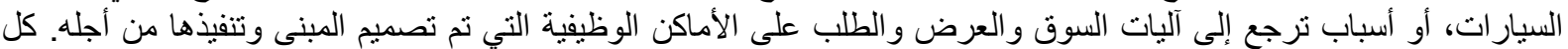

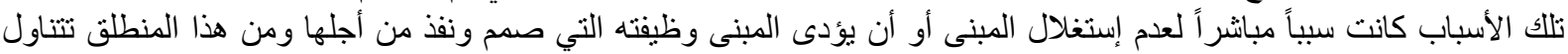

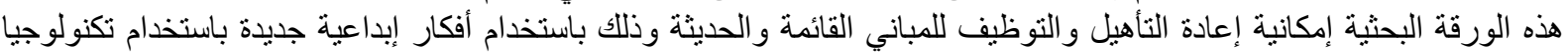

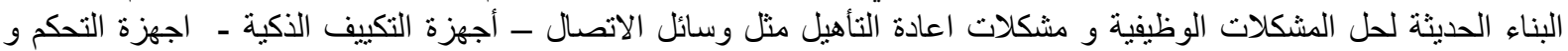

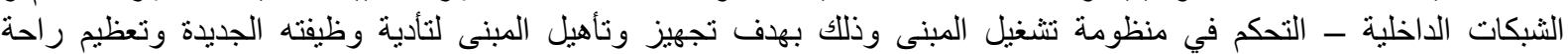

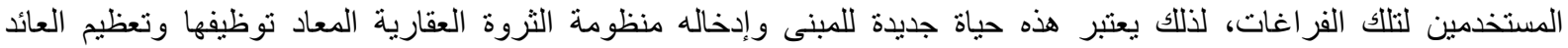

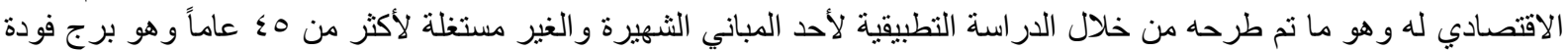
منطقة الجزيرة ومن خلال تللك الدراسة خلص البحثث إلى مجموعة معايير لإعادة التأهيل والتوظيف في إطار استخدام الفكر الإبداعي التكنولوجي خارج إطار الحلول التقليدية. 


\section{INTRODUCTION}

Rehabilitation is generally considered to be less substantial than renovation even though it usually involves repair of all the building's basic systems and elements of construction, Repair may include replacement or strengthening of deficient or damaged structural elements. Repair of leaks and damage to roofs and exterior walls, windows and doors also are typically included.

During a rehabilitation, the building's systems are brought into general conformance with local codes and ordinances. Occasionally, special rehabilitation and make it easier to achieve conformance, such sections typically allow for the possibility of "grandfathering" pre-existing deficiencies or "archaic," non-conforming construction systems and techniques through a series of tradeoffs. Installation of sophisticated life safety alarm systems or automatic fire suppression systems are commonly requested tradeoffs.

\section{RESEARCH OBJECTIVES}

This study discusses the subject of "rehabilitation" as one of the most widespread architectural conservation methods in our world today, and presents the status of international rehabilitation projects, and highlight how to rehabilitate them with the view of the modern technology system of modern construction

The main objective of this study is to shed light on the experience of the Foda Tower in Zamalek, Cairo, to find out the mechanism of rehabilitation and to identify the history of the building and the secrets of stopping the work and how to re-qualify again in 2018 with the system of modern construction technology (Coffey, 1994)

\section{RESEARCH METHODOLOGY}

The research follows the experimental analytical methodology, where a theoretical study is carried out in which the concept of rehabilitation, rehabilitation features, rehabilitation stages, models of international projects, field study and analysis of the current status of the tower are analyzed and followed by three proposed alternatives and analysis in terms of proposed rehabilitation axis and design idea And the program of distribution of spaces and elements that have been rehabilitated and feasibility study of the alternative and proposed technological studies and the possibility of using renewable energies, and finally choose the best model and results and recommendations.

\section{THEORETICAL APPROACH}

Where we know the concept of rehabilitation and its characteristics and stages of rehabilitation and its function, and then review a range of international experiences in rehabilitation.

\subsection{Rehabilitation Definition}

It means finding a new job for the building so that it can be utilized and exploited, while at the same time guaranteeing continuity and preserving it, when we are exposed to the trends and policies of contemporary Egyptian in dealing with buildings, we find that they are divided into (Kinkel \& Muthesius, n.d):

- Negative maintenance of the building with an attempt to treat negative impacts in the environment and surrounding conditions.

- To maintain the positive elements of the building without change or add to remain the building as a museum of that era. 
- Positive maintenance as well as development and modernization to qualify for reuse.

\subsection{Rehabilitation Advantages}

There are many advantages of rehabilitation, including social, cultural and economic aspects, as follows:

- Social characteristics: People and cities keep their identity and their social origins, while at the same time keeping up with the times.

- Cultural characteristics: preserves the art, architecture and monuments.

- Economic advantages: Reuse the existing building, and be more economical than demolition and reconstruction and the accompanying costs to remove the rubble.

\subsection{The Stages of Rehabilitation in Building}

The process of rehabilitation of the building goes through several stages, from the study and the collection of information to the development of plans and implementation, these stages are not separate but are intersecting and overlapping with each other. They can be summarized below (DiPasquale \& Wheaton, 1996):

1. Collection of information from architectural documents about the building of books, government records, any images or drawings available about the building and around it to know the architectural value of the building and the extent of the change in the building.

2. Evaluate the current structural state of the building with an accurate description of the weaknesses in the building materials of cracks and damage and others.

3. Evaluate the architectural and symbolic state of the building (strengths, weaknesses, elements giving the building value, stages of construction, additions and elements lost, original building function, and other functions) (Borsay, 2000)

4. Develop the proposed rehabilitation scheme, considering the local code used in the country or any laws including this plan (important elements to be preserved, additions that distort the building and must be removed, elements to be rebuilt, and redesigning the interior)

4.4 Rehabilitation Function (Rolftaschen, n.d)

When we decide that we are going to do the rehabilitation of the building, we expect one of three things ( Rashwan \& Fathy , 2006):

First: Use of the valuable building in its original function: As it does not change the use of existing spaces, but some modern service systems are added, for example the building of the Egyptian Diplomatic Club.

Second: Use it as a museum of art or civilization: Where it requires some special specifications such as the existence of historical value or symbolic art, For example Ahmed Shawki Museum, Taha Hussein Museum ( Rashwan \& Fathy , 2006).

Third: Using it in a modern function: These buildings have great potential for change and modification in the distribution of spaces and paths within the building. 


\subsection{Renovation and Rehabilitation of Buildings}

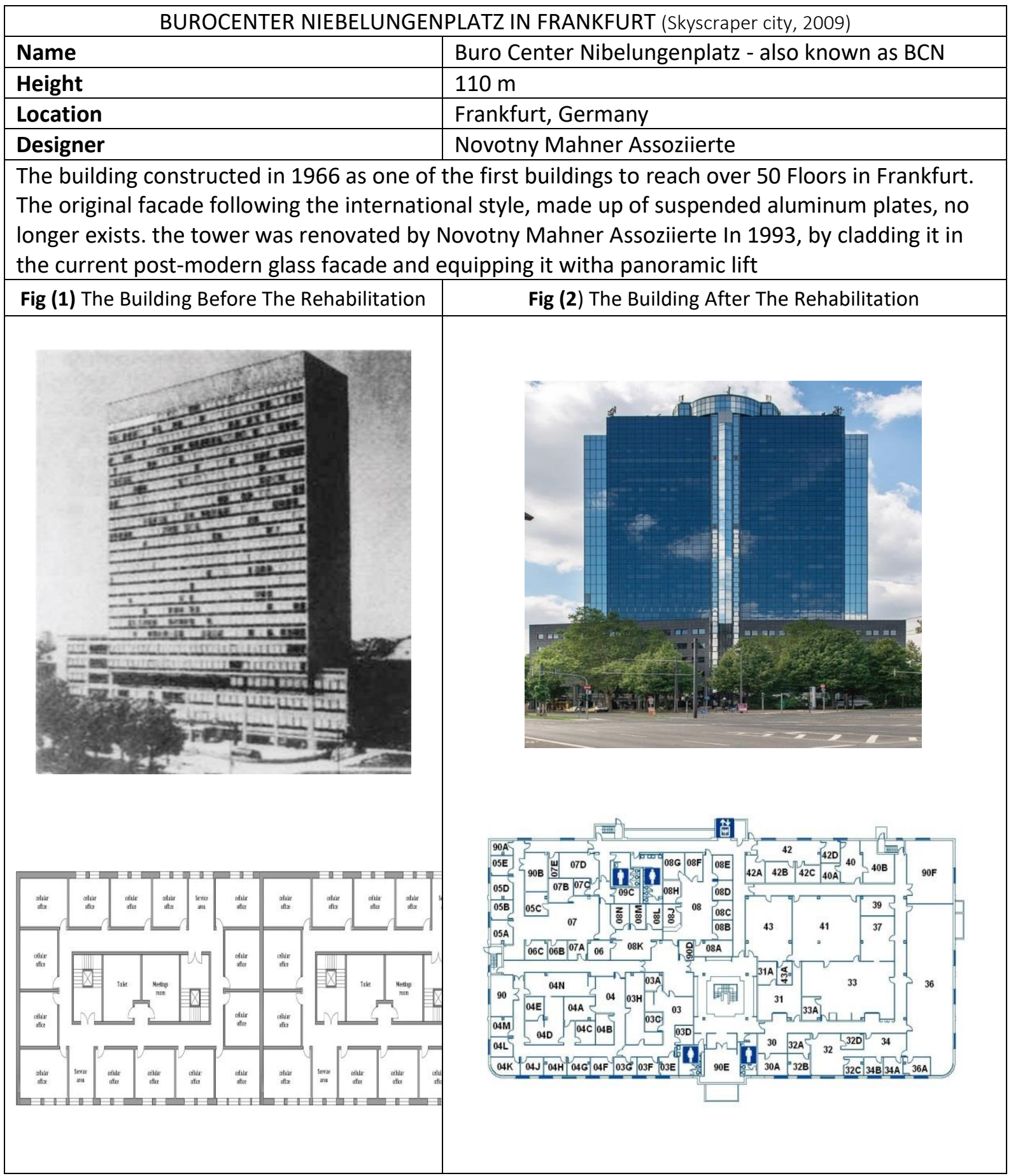

(Skyscraper city, 2009) 


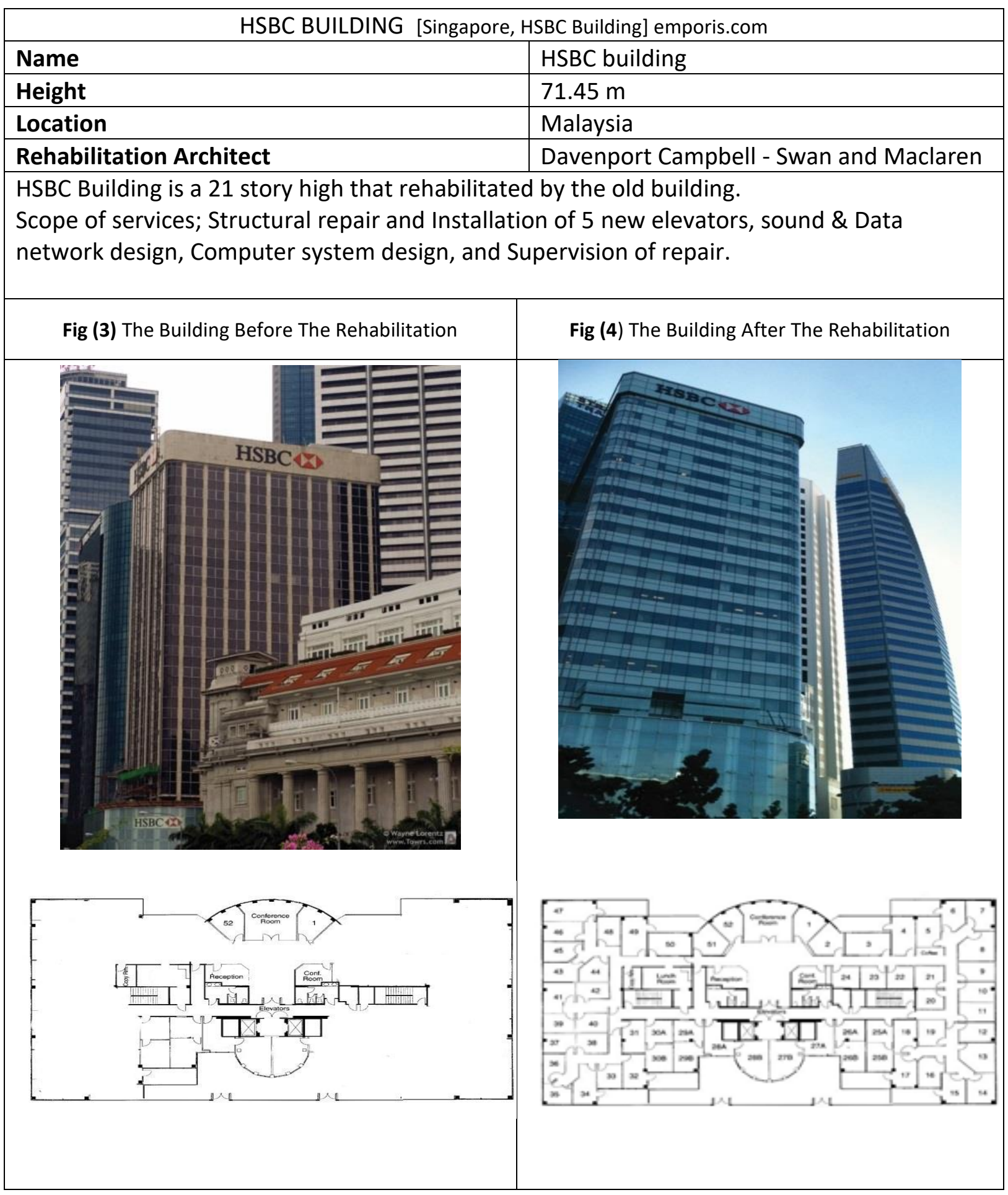

[Singapore, HSBC Building] emporis.com 


\section{ANALYTICAL APPROACH, CASE STUDY}

In this part, ELGazirah Tower "Foda Tower", was chosen to be the applied state due to its value as indicated in the following table. Table 1.

Table1. The first skyscraper in Egypt Foda Tower.

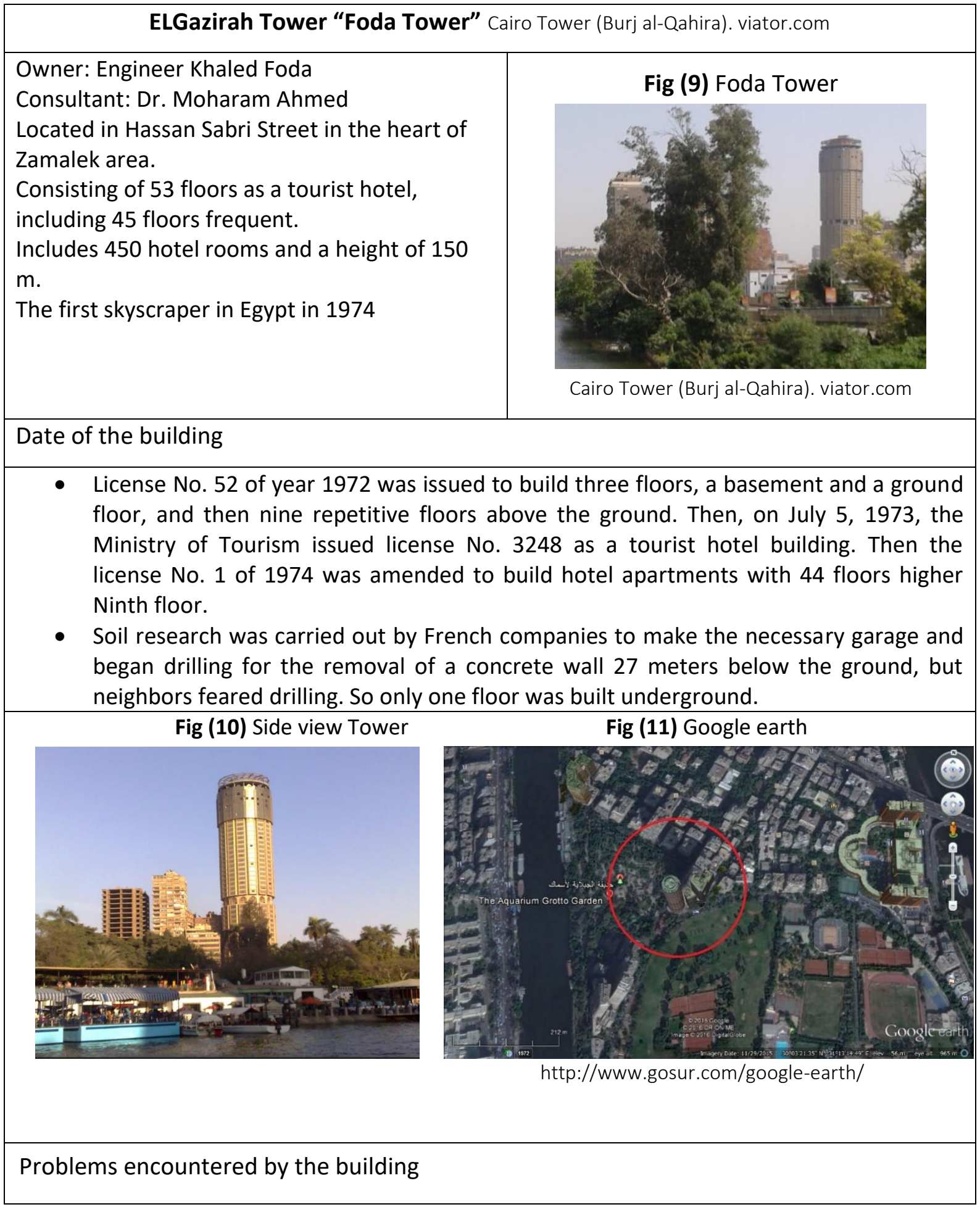


There is a range of political problems that we have not addressed, but we will talk about the problems stated, such as, the governor of Cairo refused to connect the public facilities to the building and was dissolved by the Court, and there is no special garage for the hotel, which has not been solved yet.

Fig (12) The road between the tower and the police point, showing the narrow sidewalk in front of the tower

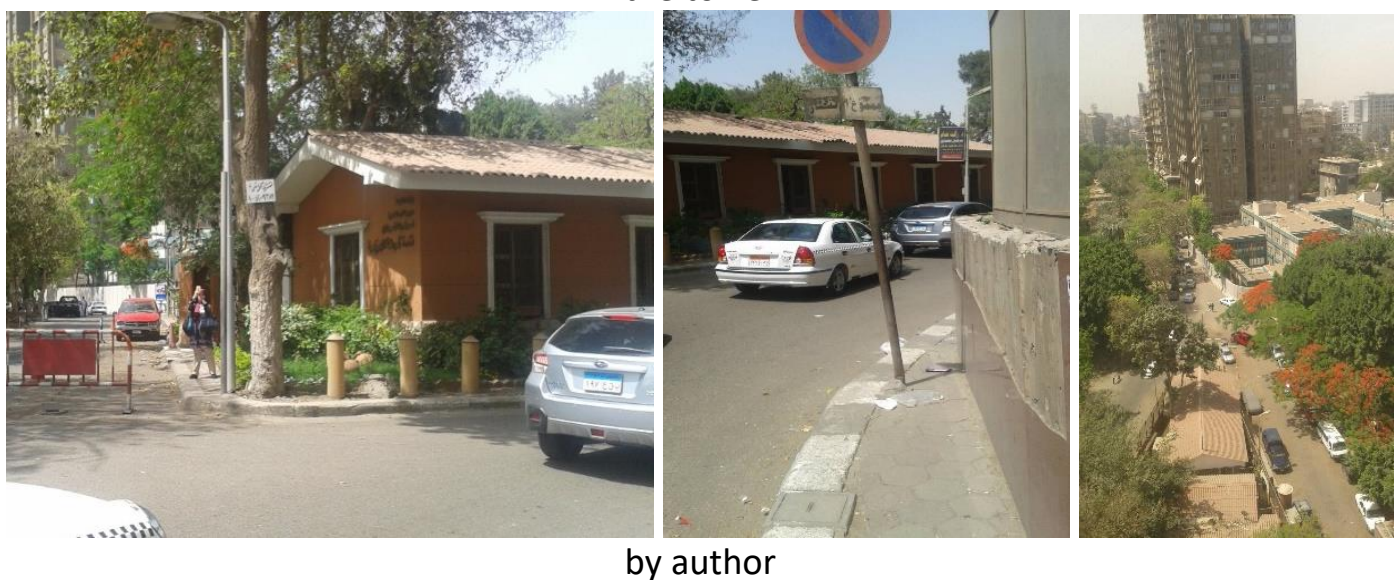

The suggestions that were mentioned to solve the problem of garage, which are as follows:

- Buy a villa close to the hotel to build a garage below them to serve the hotel's purposes.

- Building a garage below the ELGazirah club.

- Building the garage in the neglected part of the fish garden.

- Building the garage below Hassan Sabri Street.

Architectural description of the tower

The ground floor is the entrance to the hotel, followed by the floor of Mezzanine for management, the first floor is a restaurant, kitchen + services, from the first floor to the eighth, they are general roles, where the ballroom contains a concert hall

From the 9th to the 20th floor (hotel rooms).

The 21st and 22nd cycles of Electromechanical works.

From the 23rd floor to the 39th floor are residential floors (rooms and suites)

The 40th floor and 45th round (general roles), knowing that there is in the 45th floor (health club and Jacuzzi)

The last floor is a height of two floors, which is a revolving restaurant along with services from the kitchen and other services and a large elevator

Fig (13) The plan of the tower is circular and consists of 16 external columns and 8 internal and 7 lifts for the public and 2 for service, each floor consists of 16 parts, where the parts are combined to form wings according to vision by author

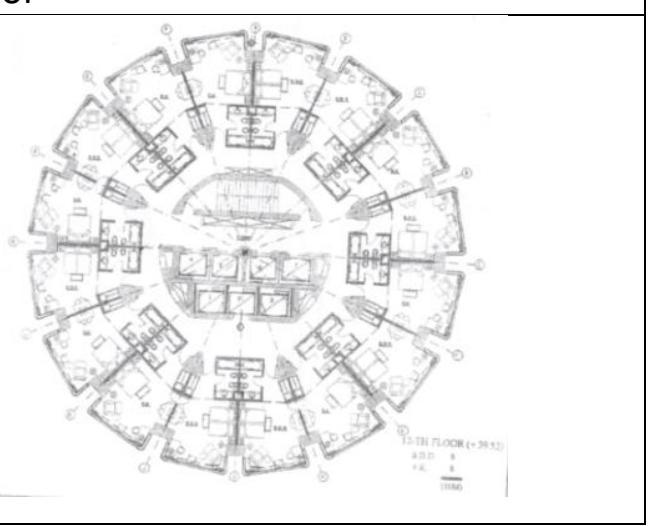




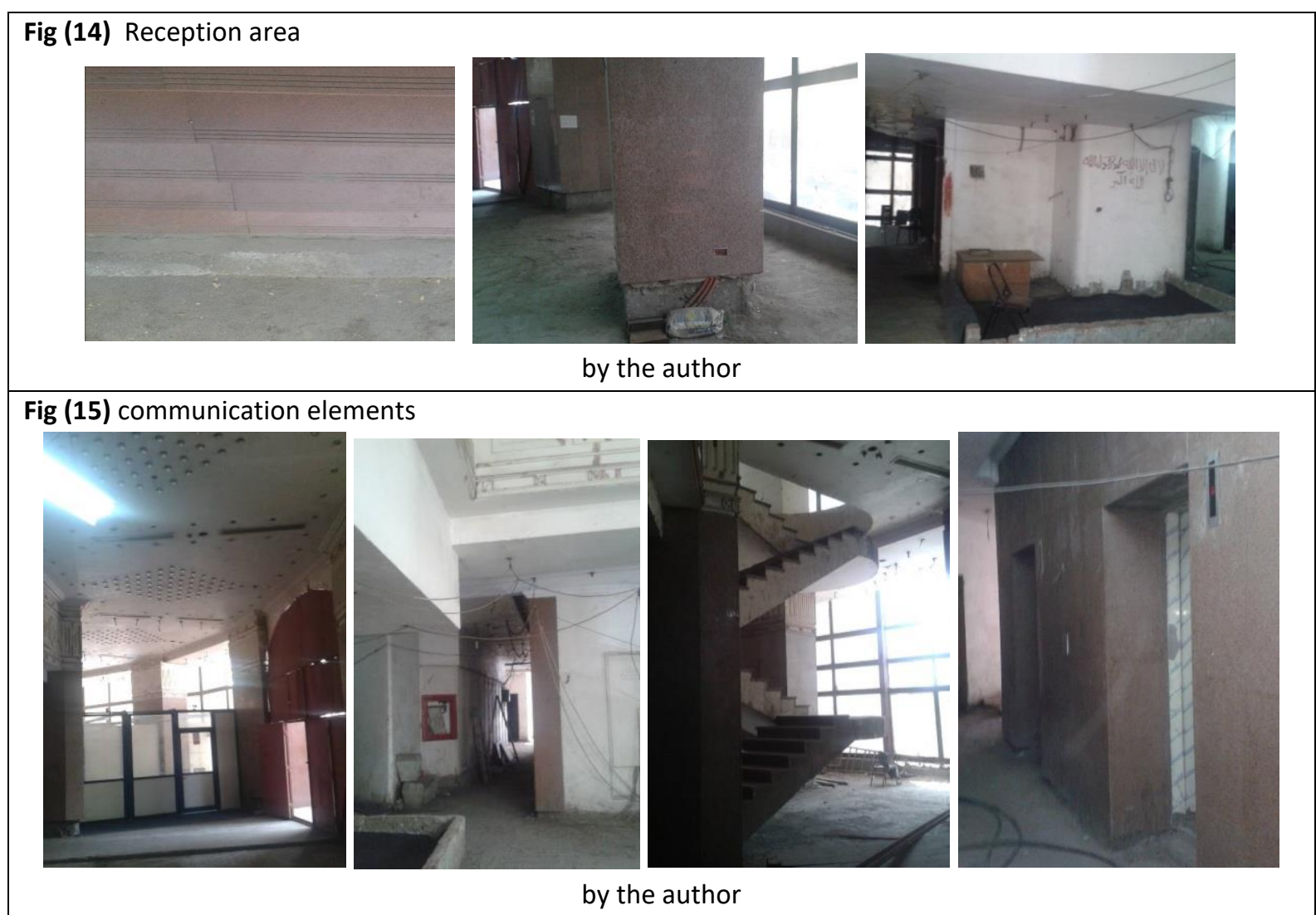

Fig (16) The interior furniture of the rooms
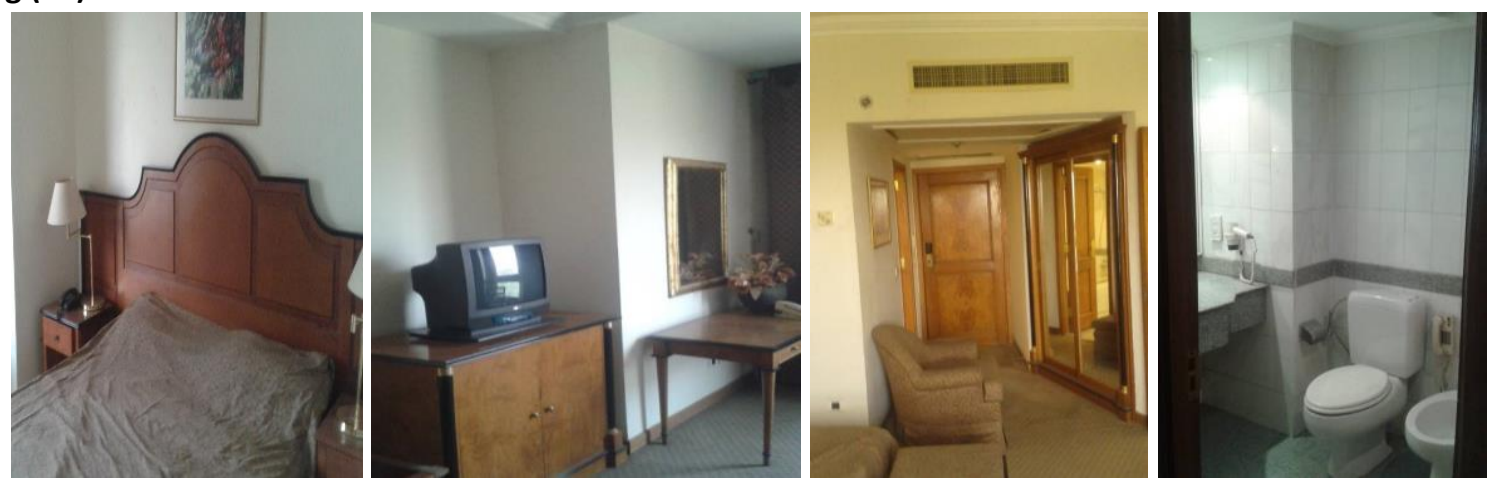

by the author

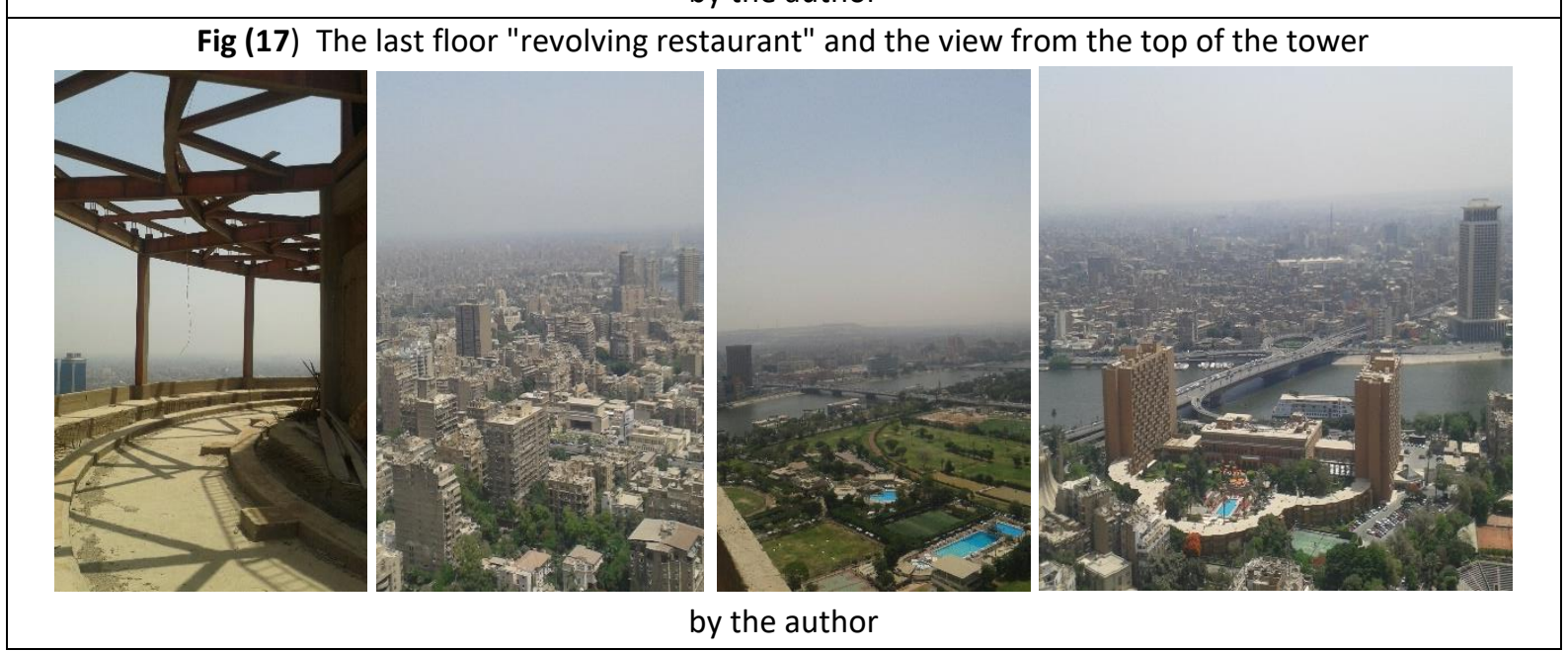

5.1 Rehabilitation Suggested Axis for Case Study 
An Approach towards the Rehabilitation of the building case study

- Rehabilitation of existing old and vacant buildings adds new resources that promote the rebirth of the declining inner city.

- The buildings that are aging due to the lack of maintenance and non-utilization once rehabilitated, give a new look to the declined urban center, thereby inviting new residents.

- Rehabilitation of buildings will enhance the city's tax base by bringing active additions to the existing tax base, and also by creating a positive momentum in the local economic structure due to increased commercial activities in the city.

- A focus on building rehabilitation as an important factor of overall urban revitalization efforts achieves significant cost savings in providing new buildings and infrastructure for growing needs.

- Rehabilitated buildings increase the existing building stock in the city, opening broad opportunities for home and business ownership.

- The process of building rehabilitation brings in new population, which increases the rate of usage of the available infrastructure and services such as utility systems, transportation networks, and recreational and cultural centers.

\section{Assessment Method}

The assessment is based on a visual inspection of the buildings including where it is possible, visual inspection of all units and shared parts (where such exist).

During the survey all the information gathered is registered in checklist according to the criteria defined in the application instructions developed for this purpose (Pedro 2008b).

This indicator may also be used to determine the buildings' rehabilitation and maintenance feasibility.

To ensure a rigorous, objective and independent assessment of the building, the survey is divided into the assessment of: the constructive and functional elements, and the spaces belonging to each building.

For each functional element the assessment begins by determining the existence of defects and classifying their severity in a four-point scale according with the criteria presented in Table 2 .

Table (2) Rules for assessing the severity of the construction defects

\begin{tabular}{|llll|}
\hline Very slight & Minor & Medium & Severe \\
\hline $\begin{array}{l}\text { Absence of defects } \\
\text { or defects with no } \\
\text { expression }\end{array}$ & $\begin{array}{l}\text { Defects prejudicial } \\
\text { to aesthetics }\end{array}$ & $\begin{array}{l}\text { Defects prejudicial to } \\
\text { use or comfort }\end{array}$ & $\begin{array}{l}\text { Defects that endanger } \\
\text { health or safety }\end{array}$ \\
\hline
\end{tabular}

The Level of rehabilitation needs is defined in three categories: Slight, Medium and Severe, according to the criteria presented in Table 3. 
Table 3. Criteria for assessing the level of rehabilitation

\begin{tabular}{|l|l|l|}
\hline Slight rehabilitation & Medium rehabilitation & Severe rehabilitation \\
\hline Includes: & Includes: & Includes: \\
- Execution of coatings & - Replacement of coatings; & - Repair, replacement or \\
repairs; & Repair and creation of new & reinforcement of primary \\
- Minor repairs on building's & facilities; or secondary \\
premises; & Localized repair, & constructive elements. \\
- Localized repairs and of & replacement or & \\
reduced complexity in the & reinforcement of primary \\
primary and / or secondary & and / or secondary \\
elements. & constructive elements. & \\
\hline
\end{tabular}

\subsection{Proposed Technology}

\subsubsection{Renewable Energy}

Biomass is a renewable energy source not only because the energy in it comes from the sun, but also because biomass can re-grow over a relatively short period of time compared with the hundreds of millions of years that it took for fossil fuels to form. Through the process of photosynthesis, chlorophyll in plants captures the sun's energy by converting carbon dioxide from the air and water from the ground into carbohydrates-complex compounds composed of carbon, hydrogen, and oxygen. When these carbohydrates are burned, they turn back into carbon dioxide and water and release the energy they captured from the sun.

\subsubsection{Building skin - The visualized energy}

The structure along with the skin reacts to views, circulation, and program requirements. The skin reacts to the energy of the site by curling open and closed as the temperature fluctuates. This process is made possible by utilizing a thermo bimetal, which turns the building into a living and changing structure reacting to the unique sun conditions each day. The skin is strategically placed around views and interior space planning. The building's inflatable southern façade is segmented into organic triangular shapes that mesh with the surrounding nature.

\subsubsection{Parametric planting}

Connect the containers designated for separation of organic materials and recycling (used as fertilizer) to the facade of the building in order to beautify them. Design of composting boxes or (units) where there is (compiling / sorting) organic materials. When attached to the front of the building, thrive in green life forms! Design these containers in the cell like patterns that need to be filled with all the waste that will go to the compost. Once done, these cells need to be attached to the front of the building and left there, where they thrive in green life forms, reduce $\mathrm{CO} 2$, collect rainwater and add a beautiful touch of green to the building.

\subsubsection{Carbon fiber}

These carbon nanotubes are made up of nanoparticles and are one billionth of a meter in diameter. They are made up of graphite filaments that are shaped like tubes and are characterized by a good combination of diamond and graphite characteristics. The use of 
carbon fiber in the structure of the building instead of the traditional steel structure, as it reduces the material weight by up to $90 \%$ of the steel and therefore require lighter installation equipment, and it has other benefits such as being less expensive and installed in a longer and faster construction, It is estimated that carbon fiber structures can be $20-30 \%$ faster in construction than conventional steel structures. Carbon does not rust and corrodes like a steel structure and this makes it need less maintenance.

\subsection{Design Concept}

The Design Concept For these Alternatives was based on designing a unique landmark to upgrade the skyline of Cairo and to upgrade the old building image to a very new one. As shown in table 4

Table (4) Proposed Alternatives for the Rehabilitation of Foda Tower by author

\begin{tabular}{|c|c|c|}
\hline $\begin{array}{c}\text { Fig (18) } \\
\text { ALTERNATIVE 'A' (19) }\end{array}$ & $\begin{array}{c}\text { Fig (20) } \\
\text { ALTERNATIVE 'C' }\end{array}$ \\
\hline ALTERATIVE 'B' & \\
\hline
\end{tabular}




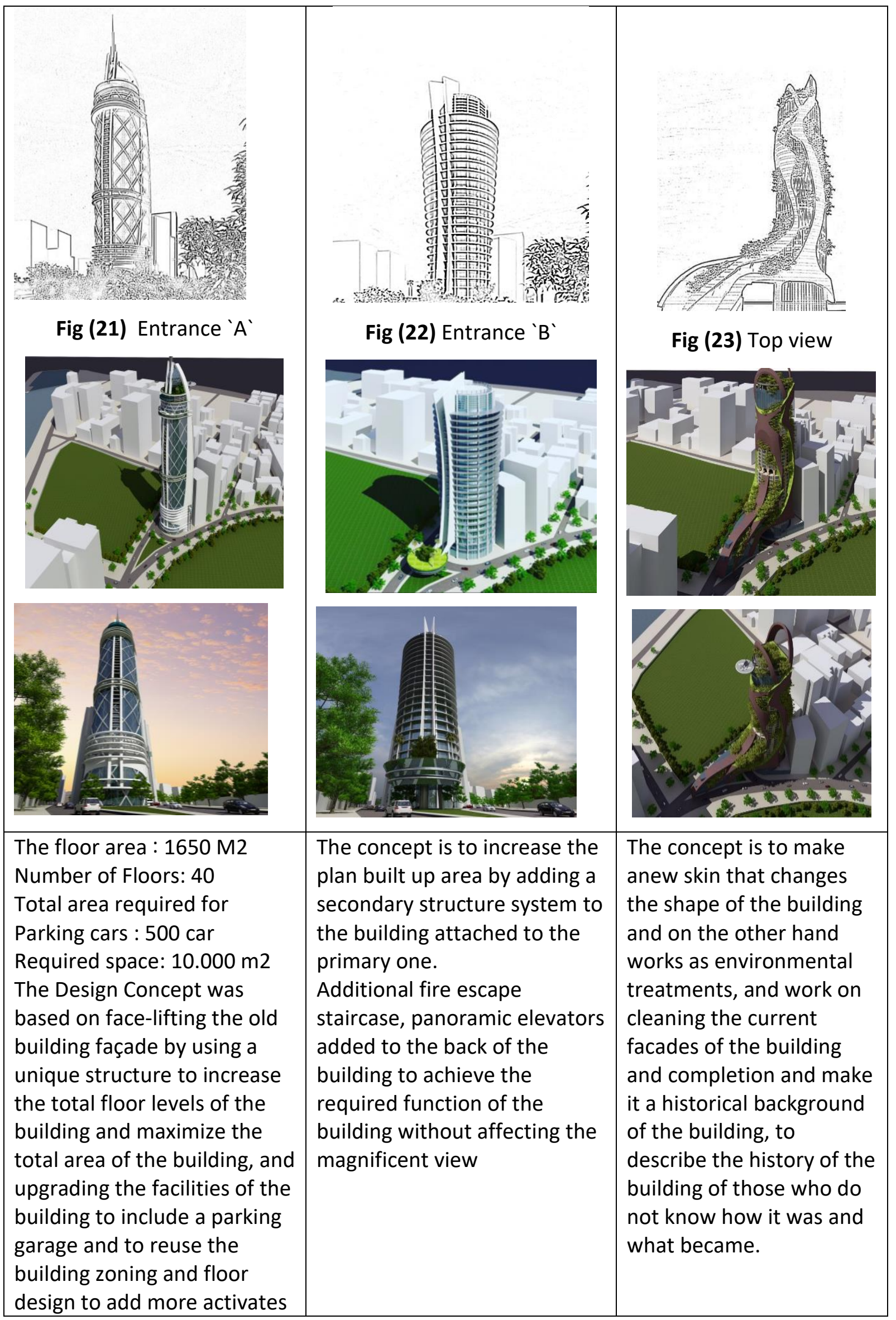




\begin{tabular}{|c|c|c|}
\hline \multicolumn{3}{|c|}{ The Rehabilitation For this building was Based on several levels } \\
\hline $\begin{array}{l}\text { On the Parking Level } \\
\text { By using a smart Automated } \\
\text { Parking with an outside } \\
\text { elevators in the first floors of } \\
\text { the building. }\end{array}$ & $\begin{array}{l}\text { On the Parking Level } \\
\text { By Adding an underground } \\
\text { automated parking to fulfill } \\
\text { the building requirements. }\end{array}$ & $\begin{array}{l}\text { On the Parking Level } \\
\text { By using the road island in } \\
\text { front of the building, and } \\
\text { building a garage consists } \\
\text { of nine floors, four } \\
\text { underground, and five } \\
\text { above the ground }\end{array}$ \\
\hline $\begin{array}{l}\text { On the Structural Level } \\
\text { By using a Diagrid Structure } \\
\text { system as an envelope to } \\
\text { surround the building to add } \\
\text { more than } 10 \text { floors above } \\
\text { the building existing height. }\end{array}$ & $\begin{array}{l}\text { On the Structural Level } \\
\text { By Adding a secondary } \\
\text { structure to increase the plan } \\
\text { cross-section }\end{array}$ & $\begin{array}{l}\text { On the Structural Level } \\
\text { Using traditional methods } \\
\text { of constructing a building, } \\
\text { and making new skin with } \\
\text { smart materials, which } \\
\text { interact with the } \\
\text { surrounding atmosphere. }\end{array}$ \\
\hline $\begin{array}{l}\text { On the Design Level } \\
\text { By upgrading the building } \\
\text { design and add unique } \\
\text { facilities to attract the Class A } \\
\text { clients in this building such as } \\
\text { the A helicopter landing pad } \\
\text { over the top of the building, } \\
\text { also a unique rotating glass } \\
\text { Dome for a different dining } \\
\text { experience and to host } \\
\text { events, with a large Antenna } \\
\text { with Led lights over the top } \\
\text { of the building. }\end{array}$ & $\begin{array}{l}\text { On the Design Level } \\
\text { by modifying the existing } \\
\text { function of the building to } \\
\text { fulfill the recent requirements } \\
\text { of the local market in Egypt, } \\
\text { the below elements added: } \\
\text { Mall, Apartments, Banquet, } \\
\text { Disco \& bar, Gym and Spa, } \\
\text { and Modifying the main } \\
\text { entrance, adding a new } \\
\text { staircase for fire escape, } \\
\text { Adding } 2 \text { panoramic elevators. }\end{array}$ & $\begin{array}{l}\text { On the Design Level } \\
\text { By keeping the original } \\
\text { use of the tower but with } \\
\text { a slight change in the } \\
\text { places of the rooms due } \\
\text { to the change in the } \\
\text { height of the buildings } \\
\text { surrounding the tower, as } \\
\text { well as adding new items } \\
\text { above the garage building } \\
\text { attached to the tower } \\
\text { such as shops and } \\
\text { restaurants, Add } \\
\text { helicopter landing pad } \\
\text { over the roof of the } \\
\text { building. }\end{array}$ \\
\hline
\end{tabular}

\subsection{Proposed Design Alternative}

By presenting the three previous alternatives and knowing their design ideas and the rehabilitation methodology used, we find that the first alternative is the closest to the current situation, since it depends on the area allocated to the building only, and not to use any other areas, making its implementation easier, in view of avoiding conflicts with government in adding any area to the land of the tower.

\subsection{Space Program}

The area of each element of the project is accurately explained in order to try to exploit each part of the existing building as a four star hotel, as shown in Table 5. 
Table (5) The space program for the proposed alternative

\begin{tabular}{|c|c|c|c|c|}
\hline \multirow{2}{*}{\multicolumn{2}{|c|}{ Function }} & \multicolumn{3}{|c|}{ Hotel } \\
\hline & & \multicolumn{2}{|c|}{320} & rooms \\
\hline & Space & \multicolumn{3}{|c|}{ Area M2 } \\
\hline \multicolumn{4}{|c|}{ Main Lobby - Total Area } & 518.4 \\
\hline \multicolumn{4}{|c|}{ Administration Areas - Total Area } & 351.6 \\
\hline \multicolumn{4}{|c|}{ Total Housekeeping Area } & 153.6 \\
\hline \multicolumn{4}{|c|}{ Total Laundry Service Area } & 524.8 \\
\hline \multicolumn{4}{|c|}{ Total Restaurants Area } & 672 \\
\hline \multicolumn{4}{|c|}{ Total Coffee Shops Area } & 256 \\
\hline \multicolumn{4}{|c|}{ Total Main Kitchen Area } & 1038.4 \\
\hline \multicolumn{4}{|c|}{ Total Floor Areas } & 5299 \\
\hline \multicolumn{4}{|c|}{ TOTAL ROOMS AREA } & 11200 \\
\hline \multicolumn{4}{|c|}{ Total Mechanical Areas } & 1217.8 \\
\hline \multicolumn{4}{|c|}{ Total General Strg. Area } & 566.4 \\
\hline \multicolumn{4}{|c|}{ Total Recreational \& Multipurpose Area } & 2635 \\
\hline \multicolumn{4}{|c|}{ TOTAL BUILT AREA } & 19134 \\
\hline \multirow{4}{*}{$\begin{array}{c}\text { Alternative } \\
\text { inside } \\
\text { parking }\end{array}$} & Item & Area/m2 & $\begin{array}{c}\text { No. } \\
\text { Of } \\
\text { floors }\end{array}$ & No. of cars \\
\hline & Hotel & 19500 & 30 & \\
\hline & Parking & 5200 & 8 & 355 \\
\hline & Admirative areas & 6500 & 10 & \\
\hline
\end{tabular}

\subsection{Design Analysis}

This design is based on the addition of 10 floors of parking in the tower according to the design of the new structure; the elements were distributed inside as follows. Table 6 
Table (6) The Floor Allocation in the alternative by author

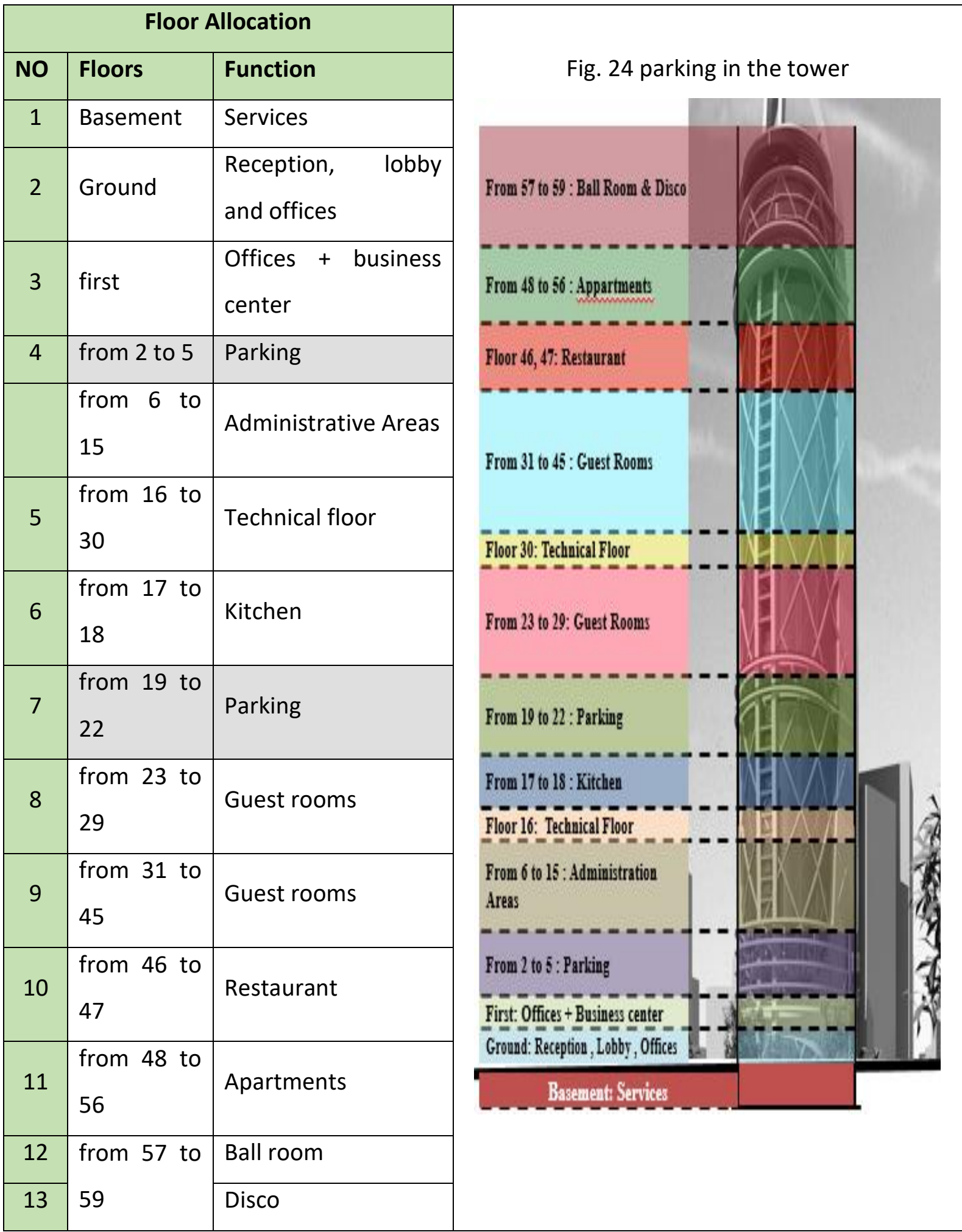

The roof garden is one of the architectural solutions in this alternative which created by adding layers of plants on top of a traditional roofing system. The layers of a contemporary green roof system, from the top down, as shown in Fig.25. 
Fig (25) The layers of a contemporary green roof system

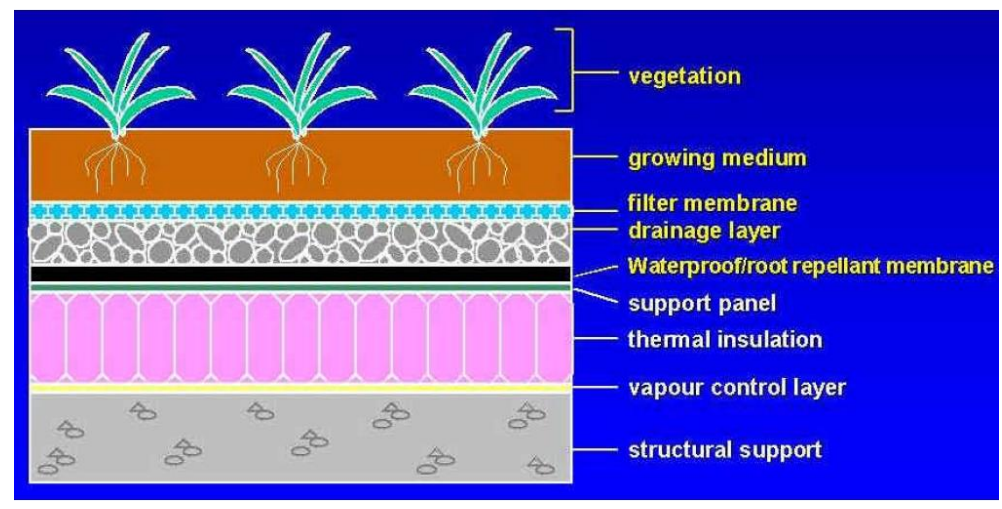

(Ellis, 2007)

As for the entrance of the hotel must be suitable for the size of the building as a land mark of the area and therefore the alternative tries to depend on emptying of the area opposite the tower to open the vision of the main entrance to the tower.

In this alternative, the parking as an automated parking designed inside the tower through an 8 floors parking over the real height of the tower. Fig.26.

Fig (26)The automated parking designed inside the tower
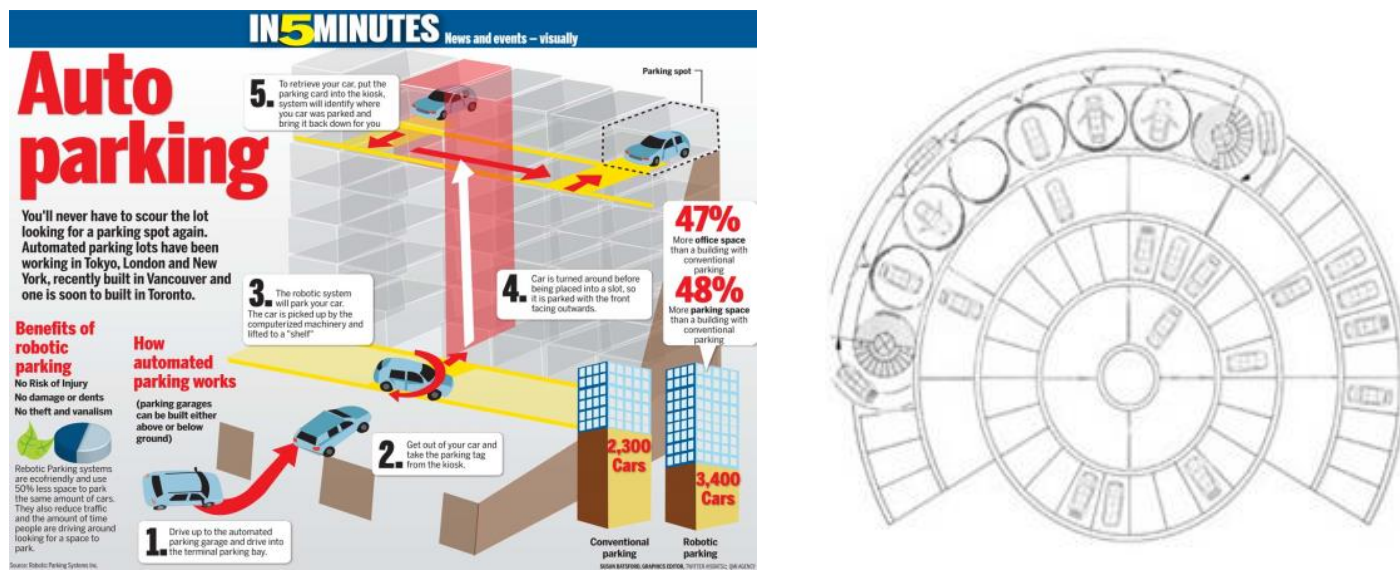

( ROTHARY Innovations AG, 2011)

\subsection{Building Technology and Renewable Energy in the Case Study}

The Structure System for the Alternative is "DIAGRID STRUCTURE", Diagrid is a design for constructing large buildings with steel that creates triangular structures with diagonal support beams, and a system of triangulated beams, straight or curved, and horizontal rings that together make up a structural system for a skyscraper. Fig.27. 
Fig (27) The DIAGRID Structure System for the Alternative
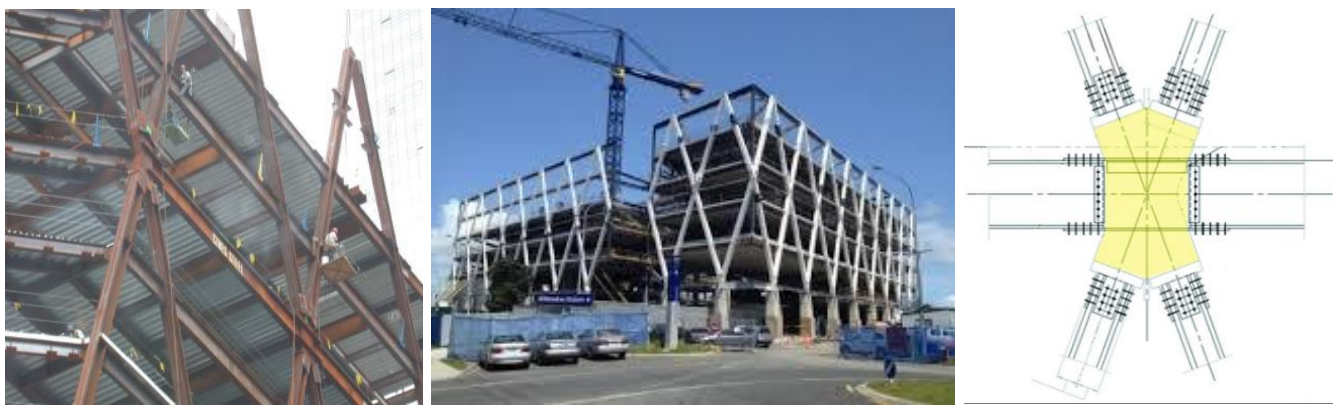

http://www.sabbour.com/portfolio-single-project.php?_=50

There are many Smart Building Approaches that can be used in the building such as use information technology during operation to connect a variety of subsystems, the solar heating and Controllers regulate, Building Electric Power Generation, Smart Finishing and Surfaces, smart windows, Sensors. Etc. Fig.28.

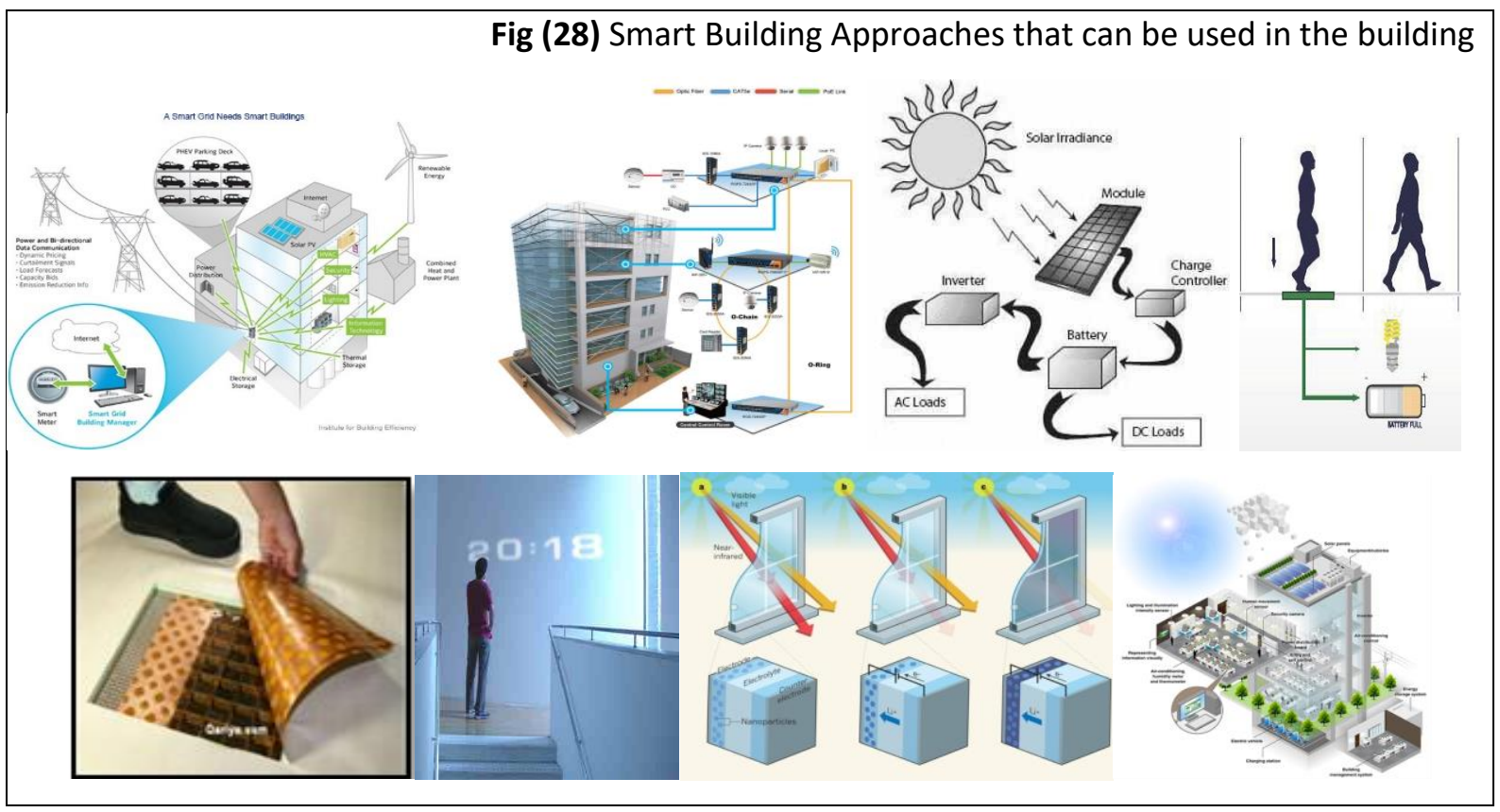

http://www.sabbour.com/portfolio-single-project.php?_=50

\section{CONCLUSION AND RECOMMENDATIONS}

The research paper summarized to a set of results \& recommendations that would put a set of standards and guidelines in the framework of organizing the concept from the practical and implementation experiences of rehabilitation from the perspective of preserving the wealth of real estate and revitalize the unused buildings and villas. 
All the criteria is concerned with encapsulate a set of points to be taken into consideration when dealing with changing and existing activities or renewing to be reused in a better way and most important of these criteria are:

\section{First: pre-design analysis:}

- Analysis and study of positive elements of the existing building to be renovated which is part of the development system while preserving as much as possible those elements as part of the existing structural assets that reduce the cost of the renovation with awareness of the possibility of development, addition or removing or reinforcing (a study to evaluate the elements of the building to determine the general state of each element and the extent of use of fixed elements that will maintain Them and the items to be changed) (Hawass, 1995)

- The importance of professional \& full awareness dealing with the spaces of the building and its structural elements while working and designing in parallel with the defined program to develop the functional elements and the needs of each, considering its location in various levels (sabbour.com)

- Define the technical and performance level of the building and the space to be renewed according to the criteria of the new functions that will be occupied and the level of technology to be installed.

- Define the design and functional program and evaluate the accommodation of the building to be rehabilitated for all activities and to take the first design decisions in the renovation (1- Add floors to the building or extended horizontal parts to accommodate the activities, 2 - Remove some interior or exterior parts from the structural elements - Walls - Ceilings to accommodate the required functions, 3 Maintaining the vertical elements "Stairs - Elevators ...") (The Long and Winding Road blog, 2016)

- Stages of designing elements

- Exploring studies of all building elements Should lead to the functional program ( Larkham , 1996)that enhancing the existing building can accommodate that would make some design decisions to add, remove or preserve some elements, there are three approaches to the design (Coffey, 1994):

1- Conservative renewal

- Its philosophy is to keep the style of the old building - applying appropriate techniques that uses the most of the same building material solutions and preserving the existing building structure.

2- Integrated renewal

- That trend is to achieve the balance between the old and the modern trend (Renovation of the existing building - add new floor - Expanding new areas) with the adaptation of modern technology to conform to the configurations of the old building - using material- system, methods and implementation of modern devices (Ecological Design Institute, nd) 


\section{3- Renewal and Comprehensive modernization}

- To restore the rehabilitation and modernization of the building in comprehensive way, which may the building become quite different from that it was before to put it on the map of contemporary with the using of all available modern technologies from new Nano material - smart electronic systems - mechanic - method of implementation without conditions even to identify the structure of the building (Abouelfath, 1998).

\section{Second: Cost Control:}

After chosen the design concept the study have to be revised by the methodology of value engineering in order to control the cost items will be used. Fixed material or the changed one without prejudice to the function and level of performance technology requested of the building.

\section{Third: Continuous management and monitoring of execution:}

Through the implementation of renovation with flexibility to change some of the elements according to the problems facing the renewal with the possibility of solutions and alternatives to the elements used without disruption the function in the main space or technical level required. The renovation, renewal, and rehabilitation of existing buildings considered as one of the trends taken an obvious role in the system of modernization from the perspective of conservation and exploitation of the real estate wealth of the old buildings or new once that would be change their functions especially after raising the prices of construction materials and land price in general. The integration of the idea of renewal and architectural rehabilitation with the application of technical and philosophical concept of architecture side by side (Abdel Fattah, 1991)

Modern building Technology plays an obvious role in the renewal systems continuously and it may be the main motivation for the rehabilitation to improve performance within the framework of the expansion of business system, investment, trade, industry and information network at the world level, as well as the accelerated modernization of advanced Technological ideas. The awareness and skill of the architect plays great role in dealing with the new and unexploited building in its ability to replace the elements and new technological - materials without prejudice to the working system in an integrated manner while preserving the elements of the building, the most valuable and the materials that can be reused or recycled within the framework of the usage and functionality.

- The importance of re-studying the set of laws for reuse and change the activity of existing buildings within the awareness framework for the importance of existing real estate assets investment, and the use of smart technology to improve practical solutions to achieve the optimal ones for building utilization problems 


\section{REFERENCES}

Larkham , P. J. (1996). Conservation and the City. London: Rutledge.

Rashwan , W. M., \& Fathy , N. (2006). Architectural Renewal Techniques (Principles and Limitations of Application. Journal of Engineering Research.

ROTHARY Innovations AG. (2011, April 17). GENERAL ADVANTAGES OF AUTOMATED PARKING SYSTEMS. Retrieved from https://www.rothary.com/automated-parking-facilityadvantages.asp: https://www.rothary.com/

Abdel Fattah, A. K. (1991). "Methods of dealing with ancient buildings and archaeological" annual symposium. the Egyptian Society of Engineers.

Abouelfath, H. (1998). "Rehabilitation of No ductile Reinforced Concrete Buildings Using Steel Systems", Ph.D. thesis. Hamilton, Ontario, Canada: McMaster University.

Borsay, P. (2000). The Image of Georgian Bath, 1700-2000: Towns, Heritage, and History. Oxford University Press; 1st edition.

Coffey, D. P. (1994). RENOVATION, REHABILITATION AND R ESTORATION OF O FFICE B UILDINGS. Construction Dimensions.

DiPasquale , D., \& Wheaton, W. (1996). Urban Economics and Real Estate Market. Englewood Cliffs, NJ: Prentice-Hall.

Ellis, H. (2007). Green Roofs-A primer. FLC Environmental center.

Hawass, K. M. (1995). "Re-employment Approach for Internal Space" PhD thesis. Faculty of Fine Arts, Helwan University.

Kinkel, S., \& Muthesius , A. (n.d). Contemporary European Arch. Vol.IV.

Rolftaschen . (n.d). Contemprary American Arch Vol.I Benedict .Laschen.

Ecological Design Institute (nd). Http://Www.Ecodes1ign.Org.

Sabbour.com. http://www.sabbour.com/portfolio-single-project.php?_=50

The Long and Winding Road blog (2016). Singapore in the 1960s - three blasts from the past retrieved from: https://thelongnwindingroad.wordpress.com/tag/collyer-quay

Skyscraper city (2009). Buildings or Skyscrapers that underwent a Renovation or Reconstruction. Retrieved from: http://www.skyscrapercity.com/showthread.php?t=811198\#/topics/811198?page2

[Singapore, HSBC Building] emporis.com. Retrieved from https://www.emporis.com/buildings/106435/hsbc-building-singapore-singapore/

Cairo Tower (Burj al-Qahira). viator.com. Retrieved from: https://www.viator.com/Cairoattractions/Cairo-Tower/d782-a24508

http://www.gosur.com/google-earth/ 


\section{Appendix}

Survey for the site visit for the building:

\begin{tabular}{|c|c|c|c|c|c|c|}
\hline & إلجمالي المسله لهة & مساحة الدور & إجمالي عدد الأدوار & موقعه بالمبني & العنصر & المبني \\
\hline & $r_{5} r \mid \varepsilon r_{1}$ & 714,34 & r & الدور الأرضي إلي الثاني & $\begin{aligned} \text { المشرخل و إدارة } \\
\text { المشروع }\end{aligned}$ & \multirow{9}{*}{ 高. } \\
\hline & $t^{5}$ rovi, V & 714,34 & 0 & V V الدور ب إلي الدور & والمطات الأفراح & \\
\hline & $r_{\rho} \circ V \backslash \varepsilon, V T$ & 714,34 & $\Lambda$ & من الدور ^ إلي الدور 10 & شركات ومكاتب & \\
\hline & 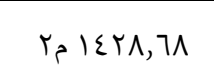 & 714,34 & r & الدور 7 ا و IV & ونداعات إحتماعات & \\
\hline & $r_{5} r \mid \varepsilon r_{1}$ & 714,34 & r & 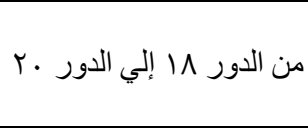 & 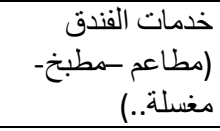 & \\
\hline & $r_{\rho} q Y \wedge 7, \varepsilon r$ & 714,34 & س & 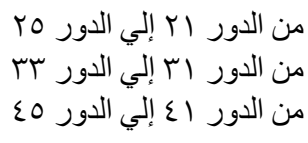 & غرف فندقية فردية & \\
\hline & $r_{0} V \backslash \varepsilon r, \varepsilon$ & 714,34 & 1. & 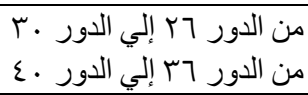 & غزد فز فندقية & \\
\hline & $r_{5} \mathrm{rOVI}, \mathrm{V}$ & 714,34 & 0 & 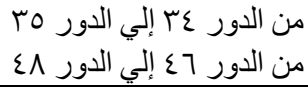 & أجنحه فندقية & \\
\hline & $r_{5} \mid \varepsilon r_{\Lambda}, 7 \Lambda$ & 714,34 & $r$ & من الدور 9ع إلي الدور م & مطعم دو ار & \\
\hline & 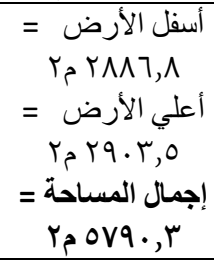 & 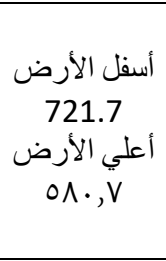 & 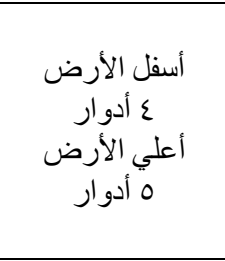 & 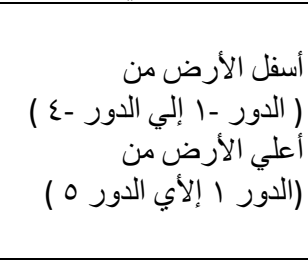 & جراج & \multirow{4}{*}{$\begin{array}{c}\overline{7} \\
\overline{3} \\
\overline{3} \\
\frac{1}{9}\end{array}$} \\
\hline & $r_{\text {م }} 580,7$ & 580,7 & 1 & الدور الأرضي & 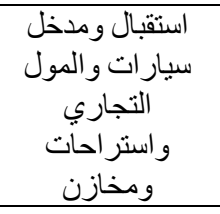 & \\
\hline & $t^{5} r \cdot v{ }^{5}$ & $\begin{array}{l}\text { V०9=7 } \\
794=V \\
719=1 \\
0 \varepsilon 1=9 \\
\varepsilon 71=1 .\end{array}$ & 0 & من الدور 7 إلي الدور 1 & محلات تجارية & \\
\hline عثر بإرتفاع الرع & $t^{5} 111 \mathrm{~V}$ & $\begin{array}{l}r 90=11 \\
r 1 \Lambda=1 r \\
r m a=1 r \\
170=1 \varepsilon\end{array}$ & $\varepsilon$ & عن الدور 11 إلي الدور & مطاعم & \\
\hline
\end{tabular}

